\title{
Evaluation of Anti-Depressant Activity of Ethanolic Extract of Justicia Gendarussa Burm with Wister Rat
}

\author{
Mythili A*, Jothimanivannan C \\ Department of Pharmaceutical Chemistry, Swamy Vivekanandha College of Pharmacy, Elayampalayam, Tiruchengode-637205, Namakkal \\ (Dt), Tamilnadu, India
}

\begin{abstract}
Objective: Justicia gendarussa Burm is an herbal plant that has several therapeutic effects. It also heals depression, grief, nervous stress and tension. In the present study we evaluated anti depressant effect of ethanolic extract from Justicia gendarussa Burm by using Forced Swimming Test (FST)[1]. Methods: Two doses of ethanolic extract of Justicia gendarussa Burm (250 mg/kg and 500 $\mathrm{mg} / \mathrm{kg}$ ) was injected intraperitoneally. Immobility time and swimming time were measured after 30 min of injection and compared with negative control and imipramine as a positive control. Result: The ethanolic extract (500mg/kg) was found to be effective and it exhibited activity similar to that of the conventional drug imipramine $(p<0.001)$ whereas $250 \mathrm{mg} / \mathrm{kg}$ dose showed higher activity with significantly increased swimming time and decreased immobility time than $500 \mathrm{mg} / \mathrm{kg}$ of ethanolic extract and imipramine. Conclusion: These results proposed $250 \mathrm{mg} / \mathrm{kg}$ of ethanolic extract was showed higher antidepressant activity than the standard.
\end{abstract}

Keywords: Justicia gendarussa Burm, Immobility time, Forced Swimming Test, Antidepressant-like effect

\section{Introduction}

Depression is a heterogeneous disorder that affects a person's mood, physical health and behavior. It is caused not only by changing lifestyle as perceived by the general public but also by some of the allopathic drugs for example, more than $15 \%$ of patients suffered in depression by using anti hypertensive drug. Especially reserpine that depletes neuronal storage granules of nor epinephrine, serotonin and dopamine. This amounts to $12.3 \%$ of the global burden of disease, and will rise to $15 \%$ at 2020 .Four hundred to five hundred million people suffer from a mental or behavioral disorder based on WHO report, yet only a small proportion of them receive even the basic treatment[2]. Various plants are being used in complementary and alternative medicines for management of depression.

A review of literature revealed that Justicia gendarussa is highly reputed plant, and has been widely employed in herbal medicine but no significant work has been carried out on the anti-depressant activity of the plant extracts. So, the present study was designed to evaluate the anti Depressant activity of ethanolic extract of Justicia gendarussa Burm and it belongs to acanthaceae family.

\section{Materials and Methods}

\section{Collection and Extraction}

The aerial part of plant Justicia gendarussa Burm was collected from the pattnamthitta, kerala in the month of December 2013. The plant was then authenticated by the joint director, the botanical survey of India, Coimbatore, Tamilnadu, India. The aerial plant material were dried in shade and pulverized. The powder were passed through sieve no.40 and used for the extraction. The extract was prepared by the cold maceration method by using ethanol and water as solvent in the ratio of 30:70. Chloroform is used as preservative. This process was carried out with stirring the mass once daily for 14 days until the extraction was completed. After completion of extraction, the solvent was removed by distillation process the dark brown color residue was obtained.

\section{Animals}

Young adult Wister rat either sexes weighing 190-250g were obtained from the animal house Swamy Vivekandha College of Pharmacy, Elayampalayam, Tiruchengode, Namakkal (Dt), Tamilnadu. They were caged in a room under standard laboratory conditions (temperature $23 \pm$ $1^{\circ} \mathrm{C}$, relative humidity $55 \% \pm 5 \%$ and lighting 08:00 20:00 h). The animals were fed on a pelleted diet and water. The Institutional Animal Ethical Committee (IAEC) approved by the protocol of this study.

\section{Phytochemical Screening}

Test for carbohydrates:

A small quantity of the extract were separately dissolved in distilled water and filtered. The filtrate was subjected to the following tests.

a. Molisch's test:

To the filtrate few drops of alcoholic $\alpha$-naphthol was added and $2 \mathrm{ml}$ of con.H2SO 4 was added slowly through the sides of the test tube. A brown coloured ring was formed at the junction of the two layers, which indicates.

b. Fehling's test:

A small portion of the filtrate was treated with fehling's solution $1 \& 2$ and then heated on a water bath. A brick red colored precipitate was formed, which indicates the presence of carbohydrates. 


\section{International Journal of Science and Research (IJSR) \\ ISSN (Online): 2319-7064}

Index Copernicus Value (2016): 79.57 | Impact Factor (2015): 6.391

\section{c. Barfoed's test:}

A small portion of the filtrate was treated with barfoed's reagent. A red colored precipitate was formed, which indicates the presence of carbohydrates.

\section{Test for glycosides:}

A small amount of the extracts were separately hydrolyzed with $\mathrm{HCl}$ for 1 hour on a water bath and hydrolysate was subjected to following tests:

\section{a. Legal's test:}

To the hydrolysate $1 \mathrm{ml}$ of pyridine, few drops of sodium nitroprusside solution were added and then made alkaline with $\mathrm{NaOH}$. A pink color was formed, which indicates the presence of glycosides.

\section{b. Baljet's test:}

The hydrolysate was treated with sodium picrate solution. A yellowish orange color was formed, which indicates the presence of glycosides.

\section{c. Borntrager's test:}

The hydrolysate was treated with $\mathrm{CHCl} 3$ and the $\mathrm{CHCl} 3$ layer was separated. To this add equal quantity of dilute NH3 solution. Pink color was observed in ammonical layer, confirmed the presence of glycosides.

\section{Test for phenolic compounds and tannins:}

The extracts were diluted separately with distilled water and filtered. The filtrate was treated with following reagents.

a) Ferric chloride test:

The filtrate was treated with $5 \% \mathrm{FeCl} 3$ solution. A violet precipitate was formed which indicates the presence of phenolic compounds and tannins.

b) Test with lead acetate solution:

Few ml of filtrate was treated with lead acetate solution, a white precipitate was formed which indicates the presence of phenolic compounds and tannins.

\section{Test for phytosterols and triterpenoids:}

A small quantity of extracts was dissolved in $5 \mathrm{ml}$ of $\mathrm{CHCl} 3$ separately and the $\mathrm{CHCl} 3$ was subjected to the following tests:

\section{a) Salkowski test:}

To $1 \mathrm{ml}$ of the above prepared $\mathrm{CHCl} 3$ solution, a few drops of con.H2SO4 added. Red color indicates the presence of phytosterols. Yellow color indicates the triterpenoids. b)

Libermann-burchards test:

The above $\mathrm{CHCl} 3$ solution was treated with few drops of acetic anhydride solution boiled and cooled. Then added con $\mathrm{H} 2 \mathrm{SO} 4$ from the side of the test tube, brown ring is formed at the junction of two layers. Green color was produced in the upper layer; show the presence of phytosterols and deep red color indicates the presence of triterpenoids.

Test for alkaloids:

A Little amount of extracts was stirred separately with a few $\mathrm{ml}$ of dil. $\mathrm{HCl}$ and filtered. And conducted following tests.

a) Mayer's test:

To the small amount of filtrate added few drops of Mayer's reagent. A white color precipitate was formed, its indicating the presence of alkaloids.

b) Dragendroff's test:

To the small amount of filtrate added few drops of dragendroff's reagent. An orange red color precipitate was formed, indicating the presence of alkaloids.

c) Wagner's test:

To the small amount of filtrate added few drops of wagner's reagent. A brown color precipitate was formed, indicating the presence of alkaloids.

\section{Test for proteins and free aminoacids:}

Small quantities of extracts were dissolved separately in a few $\mathrm{ml}$ of water and were subjected to million's, biuret, ninhydrin test.

a) Million's test:

The above solution of extract was treated with million's reagent. Appearance of red color shows the presence of proteins and free aminoacids.

b) Biuret test:

To the extract solution equal volume of $5 \% \mathrm{w} / \mathrm{v} \mathrm{NaOH}$ and four drops of $1 \% \mathrm{w} / \mathrm{v} \mathrm{CuSO} 4$ solution were added. Pink or purple color was formed indicating the presence of proteins and free aminoacids.

c) Ninhydrin test:

The extract solution was treated with ninhydrin reagent. Purpl color was produced, indicating the presence of proteins and free aminoacids.

\section{Test for flavanoids:}

The extract were dissolved separately in alcohol and then subjected to the following tests: 


\section{International Journal of Science and Research (IJSR) \\ ISSN (Online): 2319-7064}

Index Copernicus Value (2016): 79.57 | Impact Factor (2015): 6.391

a) Ferric chloride test:

To a small quantity of alcoholic solution of extract few drops of neutral ferric chloride solution was added. Blackish red colour was observed, showing the presence of flavanoids.

b) Shinoda test:

To an alcoholic solution of extract a small piece of magnesium ribbon was added along with conc. Hcl. Magenta colour was found showing the presence of flavanoids.

c) Fluorescence test:

Alcoholic solution was seen under uv light. Green fluorescence was observed, indicating the presence of flavonoids.

\section{Test for saponins:}

d) Foam test:

The extract was separately diluted with $20 \mathrm{ml}$ of dis. Water and it was agitated in a graduated cylinder for $15 \mathrm{mins}$. a $1 \mathrm{~cm}$ layer of foam was formed indicating the presence of flavonoids.

\section{Test for fixed oil and fat:}

a. Spot test:

A small quantity of extract was separately pressed between two filter papers. Oil stain was not observed, shows absence of fixed oil and fat.

b. Saponification test:

Few drops of $0.5 \mathrm{~N}$ alcoholic potassium hydroxide were added to a extract along with a few drops of phenolphthalein. The mixture was heated on a water bath for about 1 to 2 hours. Formation of soap or partial neutralization of alkali indicated the presence of fixed oil and fat.

\section{Test for mucilage and gum:}

Small quantities of extract were added separately to $25 \mathrm{ml}$ of absolute alcohol with constant stirring and filtered. The precipitates were dried in oil and examine for its swelling properties. Swelling indicates the presence of mucilage and gum. The extract was screened for the presence of various phytochemical constituents employing standard screening test. The extracts were subjected to following chemical tests to detect the chemical constituents present in this study $[3,4,5]$

\begin{tabular}{|l|c|c|}
\hline S.No & Phytoconstituent & Inference \\
\hline 1. & Carbohydrates & + \\
\hline 2. & Glycosides & + \\
\hline 3. & Saponins & - \\
\hline 4. & Proteins & + \\
\hline 5. & Alkaloids & + \\
\hline 6. & Phytosterols & + \\
\hline 7. & Flavanoids & + \\
\hline 8. & Tannins & + \\
\hline
\end{tabular}

\section{Anti-Depressant Screening}

\section{Forced swimming test (FST)}

Either sex of rats were individually forced to swim in an open cylindrical container and container diameter is 10 $\mathrm{cm}$, height is $25 \mathrm{~cm}$. Cylindrical container filled by $19 \mathrm{~cm}$ of water at $25 \pm 1{ }^{\circ} \mathrm{C}$. Either sex of rats was divided in four different groups. The first group assigned as control receiving only vehicle $(\mathrm{NaCl} 5 \mathrm{ml} / \mathrm{kg})$. The other two groups received acute dose based on acute toxicity studies of EJG $(250-500 \mathrm{mg} / \mathrm{kg})$. The Group II received standard drug Imipramine dose is $30 \mathrm{mg} / \mathrm{kg}$. The total duration of immobility was recorded during the last $4 \mathrm{~min}$ of the 6min period. Rats were ceased struggling and remained floating motionless in the water, making only those movements necessary to keep its head above water when each mouse judged to be immobile. A decrease in the duration of immobility is indicative of an antidepressant like effect $[6,7,8-10,11]$.

\section{Antidepressant activity by forced swim test}

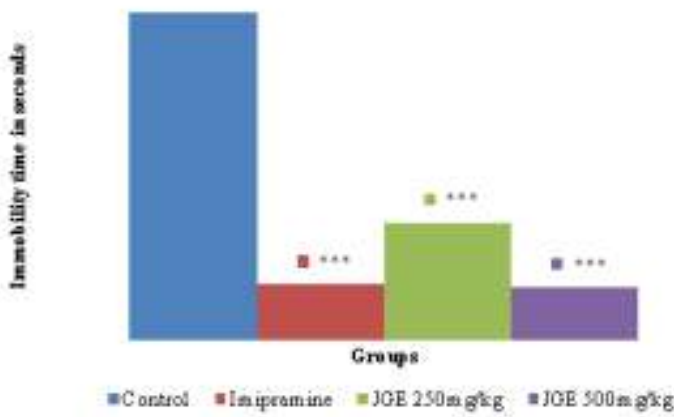

Figure 1: Antidepressant activity of JGE by Forced Swim Test.

\section{Statistical Analysis}

Data were analyzed by Prism Install version software and presented as mean \pm SEM. The statistical tests used were one way analysis of variance (ANOVA) followed by tukey-kramer Multiple comparison test. The level of statically significant ranged from $\mathrm{p}<0.05$ top $<0.001$. The results were showed in the table no- 2 . The results were graphically expressed in figure no 1. 


\section{International Journal of Science and Research (IJSR) \\ ISSN (Online): 2319-7064}

Index Copernicus Value (2016): 79.57 | Impact Factor (2015): 6.391

Table 2: Antidepressant activity of JGE by Forced Swim Test

\begin{tabular}{|c|c|c|}
\hline Group & Treatment & $\begin{array}{c}\text { Immobilty Time In } \\
\text { Seconds }\end{array}$ \\
\hline GI & $\begin{array}{c}\text { Normal Saline } 5 \mathrm{ml} / \mathrm{kg} \\
\text { (p.o) }\end{array}$ & $142.33 \pm 5.279$ \\
\hline GII & $\begin{array}{c}\text { Imipramine } 30 \mathrm{mg} / \mathrm{kg} \\
\text { (i.p.) }\end{array}$ & $24.17 \pm 6.646 * * *$ \\
\hline GIII & JGE 250mg/kg(p.o) & $51.17 \pm 17.915^{* * *}$ \\
\hline GIV & JGE 500mg/kg(p.o) & $23.17 \pm 2.012^{* * *}$ \\
\hline
\end{tabular}

Values are expressed in Mean \pm SD. $\quad * * * \mathrm{P}<0.001$ considered extremely significant when compared to control group $(n=6)[12]$.

\section{Result and Discussion}

The plant extract at the dose of 250 and $500 \mathrm{mg} / \mathrm{kg}$ were used for the in vitro antidepressant activity.The doses were selected based on the acute toxicity studies from the literature.

The antidepressant effect of Justicia gendarussa (250 and $500 \mathrm{mg} / \mathrm{kg}$ ) and imipramine were studied and observing the change in the duration of immobility by performing forced swim test. In this test Justicia gendarussa 250 and $500 \mathrm{mg} / \mathrm{kg}$ p.o produced significant reduction $(\mathrm{p}<0.05$ and $\mathrm{p}<0.001$ respectively) in the immobility period when compared with that of control group animals that received only the vehicle. The extract $(500 \mathrm{mg} / \mathrm{kg}$ )was found to be effective and it exhibited activity similar to that of the conventional drug imipramine $(\mathrm{p}<0.001)$. The results are tabulated in table.

The preliminary phytochemical screening indicated the presence of in Justicia gendarussa Burm, have been shown to possess anti- depressant effect Flavonoids, Alkaloids and Glycoside. The effect of justicia gendarussa extract may be due to the present of above said compounds. The present study proves the potential antidepressant activity of Justicia gendarussa in a dose dependent manner. We believe that Justicia gendarussa has the potential to be used as an adjuvant in the treatment of depressant and other mood disorder.

\section{References}

[1] Geone M. Correa Antonio F de C, Alcantara, Chemical constituents and biological activities of species of Justicia - a review, Revista Brasileira de Farmacognosia ; vol.22 no.1 Curitiba Jan./Feb. 2012 Epub Nov 01, 2011

[2] WHO. The World Health Report. Mental health New understanding new hope WHO Geneva 2001.

[3] Wagner.H, Bladt and E.M, Zaginski, Plant Drug Analysis, Spinger-Verlag, Berlin, 1984

[4] Khandelwal K R. Practical Pharmacognosy Techniques and Experiments. $10^{\text {th }}$ edi, Nirali Prakashan, Pune. 2006; 149-156

[5] K. C, Vallabh E. Kokate Pharmacognosy. 3rd Delhi; 2008 SRC - GoogleScholar: 107-11.

[6] Vogel G, Vogel W, Springer USA. H, and H, (Eds.). Psychotropic and Neurotropic activity. Drug
Discovery and Evaluation Pharmacological Assays 2nd Edition 1997:559-68

[7] Porsolt R D, Bertin A, Jalfre M. Behavioral despair in mice: a primary screening Test for antidepressant. Archives Internationales de Pharmacodynamic et de Theroapie, 1977; 229:327336.

[8] Steru L, Chermat R, Thierry B, Mico JA, Lenegre A, et al. The automated Tail Suspension Test. Progress in neuro-psychopharmacology \& biological psychiatry NCBI 1987;11(6):659-71.

[9] Jintanaporn W, Prasert P, Supaporn M, Kittisak S, Bungorn S, J. Evaluation of the anxiolytic and antidepressant effects of alcoholic extract of Kaempferia parviflora in aged rats. Am Bio Sci 2007;2 SRC - GoogleScholar;94-8.

[10] Kulkarni $S \underset{\text { rd }}{\mathrm{K}}$ Handbook of experimental pharmacology. 3 edition, Vallabh Prakashan New Delhi, 2005.

[11] Mora S, Díaz-Véliz G, Millán R, Lungenstrass H, Quirós S, Coto-Morales T, Anxiolytic and antidepressant-like effects of the hydroalcoholic extract from Aloysia polystachya in rats, Pharmacology, biochemistry, and behavior 2005;82(2):373-8.

[12] Jothimanivannan C, Kumar R S and Subramaniyan $\mathrm{N}$, Anti inflamatory and analgesic activity of ethanolic extract of Justicica gendarussa Burm, International Journal of Pharmacology ;2010 